\title{
Internal Capsule
}

National Cancer Institute

\section{Source}

National Cancer Institute. Internal Capsule. NCI Thesaurus. Code C13082.

A white matter structure in the subcortical region of the brain that contains a high concentration of motor and sensory projection nerve fibers. It consists of the anterior limb, genu, posterior limb, and the retrolentiform and sublentiform parts. 